Published December 2019

EKONOMIKAWAN : Jurnal IImu Ekonomi dan Studi Pembangunan

ISSN : 1693-7600 (Print), ISSN : 2598-0157 (Online), http://jurnal.umsu.ac.id/indexphp/ekawan

\title{
Upaya Peningkatan Literasi Keuangan Pengurus BUMDES Melalui Pelatihan Keuangan di Kecamatan Cimaung Kabupaten Bandung
}

\author{
Rita Zulbetti ${ }^{*}$, Perwito $^{2}$, Vina Anggilia Puspita ${ }^{3}$ \\ ${ }^{1,2,3}$ Program Studi Komputerisasi Akuntansi, Politeknik Piksi Ganesha Bandung, Indonesia \\ J1. Jend. Gatot Subroto No. 301 Bandung 40274 \\ *e-mail: zulbetti@gmail.com
}

\begin{abstract}
ABSTRAK
Kegiatan Pengabdian kepada Masyarakat ini bertujuan untuk memetakan tingkat literasi keuangan dan meningkatkan pemahaman tentang literasi keuangan pengurus BUMDes di Kecamatan Cimaung Kabupaten Bandung. Kegiatan ini dibagi menjadi tiga tahap, yaitu tahap survei, tahap pelatihan serta tahap praktek. Tingkat literasi keuangan yang di survei berdasarkan konsep, yaitu pemahaman/pengetahuan, keterampilan, dan kepercayaan terhadap lembaga keuangan. Sedangkan Lembaga Jasa Keuangan yang ditanyakan meliputi Bank, Asuransi dan Perusahaan Pembiayaan. Survei awal menunjukkan bahwa tingkat literasi keuangan pengurus BUMDes yang well literate untuk Bank sebesar 38,90\% dan not literate untuk Perusahaan Pembiayaan sebesar $68,00 \%$. Dari hasil tersebut diketahui masih perlu dilakukan peningkatan program pendidikan literasi keuangan dalam rangka membuka akses pengurus BUMDes ke Bank, Asuransi serta Perusahaan Pembiayaan. Setelah pelatihan ada peningkatan tingkat literasi keuangan pengurus BUMDes well literate untuk Bank menjadi sebesar $41 \mathrm{~s}, 35 \%$ dan penurunan indeks not literate untuk Perusahaan Pembiayaan menjadi sebesar 27,35\%. Pengurus BUMDes sudah bisa membuat laporan keuangan sederhana, agar bisa memenuhi kewajiban membuat laporan keuangan bulanan dengan cara yang transparan dan jujur bagi bisnis-bisnis di BUMDes tersebut.
\end{abstract}

Kata kunci: Literasi Keuangan, Badan Usaha Milik Desa, Lembaga Keuangan 


\title{
Efforts to Increase Financial Literacy of BUMDES Management Through Financial Training in Cimaung District, Bandung Regency
}

\begin{abstract}
The Community service aims to map the financial literacy degree and to improve understanding of BUMDes management in Cimaung, Bandung. This activity is divided into three phase, namely the survey phase, the training phase and the practice phase. The level of financial literacy based on concepts, namely understanding or knowledge, skills, and trust in financial institutions. While the financial services institutions that asked includes; Banks, Insurance and Multifinance. The initial survey shows that BUMDes management board's is 38,90\% that well literate for Banks at and Sixty\% not literate for Multifinance. Moreover, the result shown of practice that there is still a need to improve financial literacy education programs in order to access BUMDes management to Banks, Insurance and Multifinance. Survey results shown that it is necessary to improve the financial literacy education program in order to open BUMDes management access to Banks, Insurance and Financing Companies. After doing training shown that the financial literacy degree of BUMDes well literate management for the Bank to $41.35 \%$ and a decrease in the not literate index for the Financing Company to 27.35\%. BUMDes management can make simple financial reports, so that they can fulfill the obligation to make financial reports for all BUMDes business units every month honestly and transparently.
\end{abstract}

Keywords: Financial literacy, Badan Usaha Milik Desa, Financial Institutions.

\section{PENDAHULUAN}

Tingkat pertumbuhan ekonomi suatu negara dalam berbagai literatur sering dihubungkan dengan tingkat literasi keuangan masyarakatnya. Jika tingkat literasi keuangan tambah tinggi maka PDB perkapita juga bertambah tinggi.

Dari banyak penelitian, diketahui bahwa di negara-negara maju seperi Eropa, Amerika Serikat serta negara-negara yang tergabung dalan OECD (Organisation for Economic Co-operation and Development) tingkat akses keuangannya rata-rata 50\% lebih tinggi jika dibandingkan dengan negara-negara yang sedang berkembang yang memiliki tingkat akses keuangan hanya rata-rata 30\%. Angka ini bisa menjadi indikator bahwa tingkat literasi keuangan negara berkembang cenderung lebih rendah daripada negara maju. Angka ini juga menunjukkan bahwa kesenjangan tingkat literasi keuangan negara berkembang dengan negara maju akan tambah lebar jika program-program yang mengarah kepada financial inclusion tidak dilakukan. 


\section{Published December 2019}

EKONOMIKAWAN : Jurnal IImu Ekonomi dan Studi Pembangunan

ISSN : 1693-7600 (Print), ISSN : 2598-0157 (Online), http://jurnal.umsu.ac.id/indexphp/ekawan

Diantara negara berkembang, tingkat akses keuangan masyarakat Indonesia cenderung lebih tinggi. Bank Indonesia dari Hasil Survey Rumah Tangga Hasil Survei Neraca Rumah Tangga 2011 menyebutkan sebanyak 48,2\% rumah tangga Indonesia sudah memiliki rekening di lembaga keuangan. Dan $45,1 \%$ yang sudah memiliki akses pinjaman ke lembaga keuangan, namun 25,9\% meminjam dari Lembaga Keuangan lainnya. Hanya 19,2\% saja yang memiliki akses pinjaman ke Bank. Umumnya masyarakat dengan penghasilan rendah masih mengandalkan pinjaman dari lembaga non keuangan.

Badan Usaha Milik Desa, selanjutnya disebut BUMDes, adalah badan usaha yang seluruh atau sebagian besar modalnya dimiliki oleh desa melalui penyertaan secara langsung yang berasal dari kekayaan desa yang dipisahkan guna mengelola aset, jasa pelayanan dan usaha lainnya untuk sebesar-besarnya kesejahteraan masyarakat Desa (Menteri Desa, Pembangunan Daerah Tertinggal, 2015).

Modal BUMDes berasal dari Pemerintah Desa, atau bisa juga dari bantuan pemerintah baik provinsi maupun kabupaten/kota, penyertaan modal atau kerjasama dengan pihak lain atas dasar saling menguntungkan, bisa juga melalui pinjaman.

Pendirian BUMDes dimaksudkan untuk dapat mendorong produktivitas warga desa. Oleh karena itu BUMDes sebagai Lembaga usaha memiliki berbagai pilihan seperti Serving (Bisnis Sosial), Banking (Keuangan), Renting (Bisnis Penyewaan), Brokering (Lembaga Perantara), Trading (Perdagangan), Holding (Usaha Bersama) atau Contacting (Kontraktor). Yang terpenting pilihan usaha yang dipilih BUMDes tidak mematikan usaha yang sudah ada.

Dengan semua kegiatan yang bisa dilaksanakan oleh BUMDes, maka kemampuan literasi dan inklusi keuangan serta pendampingan peningkatan kemampuan manajerial, keterampilan dan kewirausahaan bagi pengurus BUMDes menjadi penting untuk dilakukan.

Maka dalam rangka meningkatkan literasi Keuangan Pengurus BUMDes, maka dilakukan kegiatan Pengabdian Kepada Masyarakat yaitu berupa pelatihan Keuangan. Kegiatan ini dilaksanakan di Desa Cimaung Kabupaten Bandung. Terpilihnya Kecamatan Cimaung sebagai tempat pelatihan karena memiliki 10 Desa dan di setiap desa sudah ada BUMDes, maka total BUMDes di Kecamatan Cimaung ada 10.

Tujuan dari dilaksanakannya kegiatan pengabdian kepada masyarakat ini adalah:

1. Memetakan tingkat literasi keuangan pengurus BUMDes di kecamatan Cimaung kabupaten Bandung.

2. Meningkatkan literasi keuangan pengurus BUMDes di kecamatan Cimaung kabupaten Bandung.

\section{KAJIAN TEORI}

\section{Sistem Keuangan}

Sistem keuangan merupakan suatu jaringan dari berbagai unsur-unsur yang saling kait-mengkait yang terdiri dari rumah tangga, lembaga pemerintah, lembaga keuangan yang membentuk pasar keuangan (Mishkin, 2013) .

Secara sederhana sistem keuangan seperti tampak pada gambar 1. 


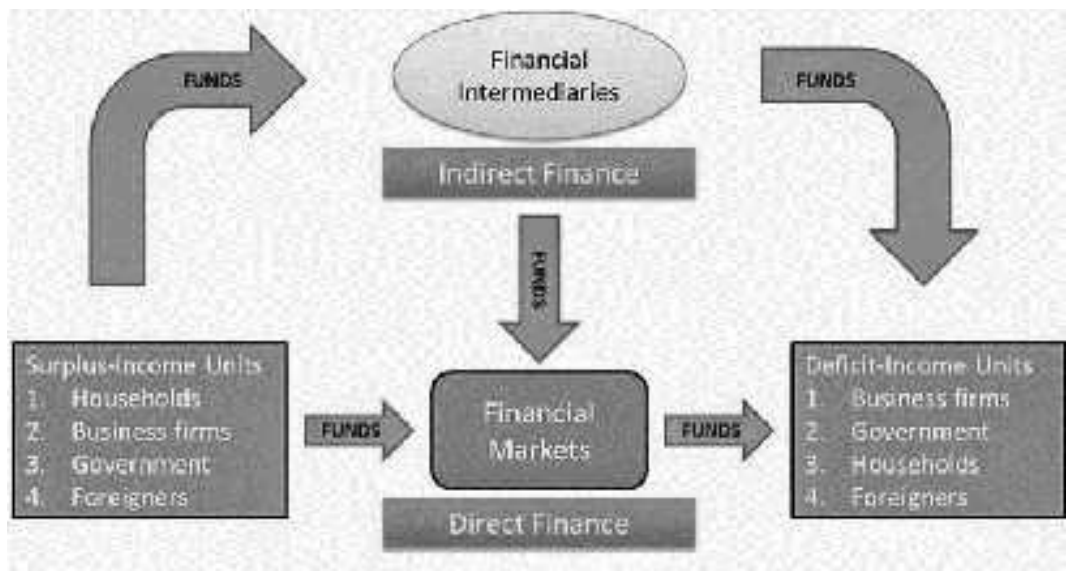

Gambar 1. Sistem Keuangan

Dari Gambar 1 di atas dapat dilihat bahwa fungsi sistem keuangan yang utama yaitu mentransfer dana dari surplus spending unit kepada deficit spending unit. Dana yang terkumpul di pasar uang akan mempertemukan pihak yang butuh dana dengan pihak yang kelebihan dana. Jadi, secara umum fungsi sistem keuangan adalah (1) menyediakan mekanisme pembayaran, (2) menyediakan kredit bagi unit defisit, (3) menciptakan uang melalui penyediaan kredit dan mekanisme pembayaran, dan (4) memberikan sarana penyimpanan dana dalam berbagai jenis simpanan.

Sistem keuangan dalam perekonomian memiliki fungsi pokok sebagai berikut, (1) fungsi tabungan, (2) fungsi penyimpanan kekayaan, (3) fungsi likuiditas, (4) fungsi kredit, (5) fungsi pembayaran, (6) fungsi risiko, dan (7) fungsi kebijakan.

\section{Lembaga-Lembaga Keuangan}

Perusahaan merupakan kombinasi dan berbagai sumber daya ekonomi, seperti: alam, tenaga kerja, modal, dan manajemen (managerial skill) dalam memproduksi barang dan jasa untuk mencapai tujuan tertentu. Adapun tujuan perusahaan antara lain adalah untuk memperoleh keuntungan maksimal, menjamin kelangsungan hidup perusahaan, memenuhi kebutuhan masyarakat serta untuk menciptakan kesempatan kerja. Selain itu, tujuan perusahaan adalah untuk memaksimumkan nilai perusahaan atau memaksimumkan kemakmuran pemegang saham.

Lembaga keuangan sangat diperlukan dalam perekonomian modern sebagai mediator antara kelompok masyarakat yang kelebihan dana (rumah tangga) dan kelompok masyarakat yang memerlukan dana (pengusaha).

Secara umum perusahaan dapat dibedakan menjadi dua, yaitu: (1) perusahaan bukan keuangan dan (2) perusahaan keuangan. Perusahaan bukan keuangan merupakan perusahaan manufaktur yang menghasilkan produk berupa barang, seperti: mobil, baja, komputer, dan/atau perusahaan yang menyediakan jasa-jasa non keuangan, seperti: transportasi dan pembuatan program komputer. Perusahaan keuangan, lebih dikenal dengan istilah lembaga keuangan merupakan perusahaan yang menyediakan jasa-jasa yang berkaitan dengan keuangan di sektor Perbankan, Pasar Modal, Perasuransian, Dana Pensiun, Lembaga Pembiayaan, dan Lembaga Jasa keuangan Lainnya (Indonesia, 2011). 
Lembaga Jasa Keuangan Lainnya adalah pegadaian, lembaga penjaminan, lembaga pembiayaan ekspor Indonesia, perusahaan pembiayaan sekunder perumahan, dan lembaga yang menyelenggarakan pengelolaan dana masyarakat yang bersifat wajib, meliputi penyelenggara program jaminan sosial, pensiun, dan kesejahteraan (Indonesia, 2011).

Secara umum lembaga keuangan berfungsi untuk menyediakan jasa sebagai perantara antara pemilik modal dan pasar uang yang bertanggung jawab dalam penyaluran dana dari investor kepada perusahaan yang membutuhkan dana tersebut. Kehadiran lembaga keuangan memfasilitasi arus peredaran uang dalam perekonomian, dimana uang dari individu investor dikumpulkan dalam bentuk tabungan, sehingga risiko dari para investor ini beralih pada lembaga keuangan yang kemudian menyalurkan dana tersebut dalam bentuk pinjaman utang kepada yang membutuhkan. Ini adalah merupakan tujuan utama dari lembaga penyimpan dana untuk menghasilkan pendapatan (Zulbetti, 2012).

Bank, bank investasi, perusahaan asuransi, perusahaan kartu kredit, perusahaan pembiayaan konsumen, dan sekuritas adalah contoh-contoh perusahaan yang menyediakan berbagai jasa yang terkait dengan uang dan investasi.

\section{Literasi Keuangan}

Definisi literasi keuangan menurut (Lusardi \& Mitchell, 2007) adalah sebagai pengetahuan keuangan dan kemampuan untuk mengaplikasikannya (knowledge and ability). Sedangkan (Atkinson \& Messy, 2013) mendefinisikan Literasi Keuangan sebagai kemampuan membaca, menganalisis, mengelola dan menceritakan tentang kondisi keuangan.

Berdasarkan pendapat beberapa ahli di atas, maka literasi keuangan didefinisikan sebagai proses/rangkaian atau aktivitas dalam meningkatkan knowledge (pengetahuan), skill (keterampilan), confident (keyakinan) masyarakat luas dan komsumen sehingga mampu mengelola dengan baik keuangan pribadinya.

\section{METODE}

Metode yang digunakan dalam pelatihan ini adalah:

\section{a. Tahap Survei}

Pendekatan yang digunakan dalam kegiatan survei ini adalah pendekatan kualitatif. Isu-isu yang akan digali antara lain meliputi tingkat pemahaman, keterampilan, dan keyakinan pengelola BUMDes terhadap produk dan layanan jasa lembaga keuangan yang terakumulasi menjadi perilaku keuangan untuk mencapai kesejahteraan.

Pelaksanaan kegiatan survei Literasi Keuangan ini dilaksanakan selama 2 bulan, mulai dari penyusunan desain survei pada awal Februari 2019 sampai dengan penulisan laporan akhir pada akhir Maret 2019. Wilayah sampel dalam survei literasi keuangan adalah 10 BUMDes di kecamatan Cimaung, kabupaten Bandung, dengan mewawancarai 2 orang pengelola di masing-masing BUMDes.

Kegiatan survei ini menggunakan instrumen berupa kuesioner untuk mengukur tingkat literasi keuangan. Kuesioner yang disusun berisi pertanyaan-pertanyaan mengenai: (1) tingkat pemahaman atau pengetahuan, (2) tingkat keterampilan, dan (3) tingkat keyakinan mengenai lembaga keuangan.

Tabel 1 memperlihatkan indikator-indikator yang digunakan dalam kegiatan survei literasi keuangan ini. 
EKONOMIKAWAN : Jurnal IImu Ekonomi dan Studi Pembangunan

ISSN : 1693-7600 (Print), ISSN : 2598-0157 (Online), http://jurnal.umsu.ac.id/indexphp/ekawan

Tabel 1.Indikator kegiatan survei literasi keuangan

\begin{tabular}{ll}
\hline \multicolumn{1}{c}{ Tingkat Literasi Keuangan } & \multicolumn{1}{c}{ Indikator } \\
\hline Pengetahuan/Pemahaman & $\bullet$ Pengetahuan tentang LJK. \\
mengenai keuangan & - Pengetahuan tentang produk dan layanan \\
& LJK \\
& - Pengetahuan tentang produk dan layanan \\
& LJK terkait fitur, manfaat, risiko, hak \\
& dan kewajiban konsumen. \\
Keterampilan mengenai keuangan & Kemampuan menghitung produk dan \\
& layanan LJK seperti bunga, hasil \\
& investasi, biaya, dan denda. \\
Keyakinan mengenai keuangan & Kepercayaan terhadap LJK. \\
\hline
\end{tabular}

Sumber: ("Measuring Financial Literacy : Questionnaire and Guidance Notes for Conducting an

Internationally Comparable Survey of Financial Literacy," n.d.)

Dalam kegiatan survei literasi keuangan ini, Lembaga Jasa Keuangan (LJK) yang ditanyakan adalah industri: (1) Perbankan, (2) Asuransi, (3) Perusahaan Pembiayaan. Sedangkan produk dan jasa lembaga keuangan yang akan diteliti terkait dengan LJK dalam kegiatan survei ini dapat dilihat pada Tabel 2 di bawah ini:

Tabel 2. LJK, produk dan layanan jasanya

\begin{tabular}{|c|c|c|}
\hline No & Lembaga Jasa Keuangan & Produk dan Layanan Jasa \\
\hline 1. & Bank & $\begin{array}{l}\text { tabungan, deposito, giro, kredit, dan } \\
\text { transfer }\end{array}$ \\
\hline 2. & Asuransi & $\begin{array}{l}\text { jiwa, pendidikan, kesehatan, kendaraan, } \\
\text { unit link, dan harta benda }\end{array}$ \\
\hline 3. & $\begin{array}{l}\text { Perusahaan } \\
\text { Pembiayaan/Multifinance }\end{array}$ & $\begin{array}{l}\text { pembiayaan konsumen, sewa } \\
\text { guna/leasing }\end{array}$ \\
\hline
\end{tabular}

Sumber: "Measuring Financial Literacy: Questionnaire and Guidance Notes for Conducting an Internationally Comparable Survey of Financial Literacy," n.d.)

Dalam kegiatan ini perolehan data/informasi dari responden dilakukan dengan teknik wawancara langsung yang dicatat ke dalam kuesioner survei.

\section{b. Tahap Pelatihan}

Metode ini adalah untuk memberikan informasi, pengenalan dan pemahaman kepada peserta tentang lembaga keuangan dan produk-produk lembaga keuangan. Materi-materi yang dipilih dalam pelatiahan kali ini adalah materi-materi yang dapat meningkatkan literasi keuangan pengelola BUMDes. Tabel 3 berikut memperlihatkan materi-materi pelatihan yang diberikan: 
Published December 2019

EKONOMIKAWAN : Jurnal IImu Ekonomi dan Studi Pembangunan

ISSN : 1693-7600 (Print), ISSN : 2598-0157 (Online), http://jurnal.umsu.ac.id/indexphp/ekawan

Tabel 3. Materi Pelatihan Literasi Keuangan

\begin{tabular}{cl}
\hline No. & \multicolumn{1}{c}{ Materi } \\
\hline 1. & Pentingnya Literasi Keuangan \\
2. & Pengertian, Prinsip Dasar dan Ruang Lingkup Literasi Keuangan \\
3. & Mengenal Otoritas Jasa Keuangan dan Industri Jasa Keuangan \\
4. & Penggunaan produk dan jasa layanan keuangan \\
5. & Bank, asuransi dan Perusahaan Pembiayaan \\
6. & Pembukuan Sederhana \\
7. & Pentingnya Pembukuan \\
8. & Laporan Keuangan
\end{tabular}

Sumber: materi pelatihan keuangan

Pelatihan dilaksanakan selama 1 (satu) hari yaitu pada hari Rabu 27 Maret 2019 dari jam 8.30 sd jam 15.00 WIB.

\section{c. Tahap Praktek}

Metode praktek ini digunakan untuk memberikan kesempatan bagi pengurus BUMDes berlatih membuat pembukuan sederhana, karena BUMDes sebagai lembaga yang menjalankan bisnis keuangan (financial business), maka BUMDes mempunyai kewajiban minimal 2 kali setahun untuk memberikan laporan keuangan seluruh usaha-usaha yang berada di bawahnya secara transparan serta jujur.

Praktek dilaksanakan pada hari Kamis 28 Februari 2019 dari jam 8.30 sampai dengan jam 15.00 WIB. Adapun materi untuk praktek ini adalah seperti yang tercantum pada Tabel 4 berikut Ini:

Tabel 4. Materi Praktek Pembukuan Sederhana

\begin{tabular}{cl} 
No. & \multicolumn{1}{c}{ Materi } \\
\hline 1. & Model Pembukuan \\
2. & Buku Kas, Kartu Utang, Kartu Piutang \\
3. & Laporan Keuangan \\
4. & Neraca \\
5. & Laporan Laba Rugi \\
6. & Laporan Perubahan Modal \\
7. & Laporan Arus Kas \\
\hline \multicolumn{2}{l}{ Sumber: materi praktek pembukuan sederhana }
\end{tabular}




\section{HASIL DAN PEMBAHASAN}

\section{Survei}

Berdasarkan hasil surveinya (Keuangan, 2017), menetapkan empat level tingkat literasi keuangan penduduk Indonesia yakni:

a. Well literate, memiliki pengetahuan dan keyakinan tentang lembaga jasa keuangan serta produk jasa keuangan, termasuk fitur, manfaat dan risiko, hak dan kewajiban terkait produk dan jasa keuangan, serta memiliki keterampilan dalam menggunakan produk dan jasa keuangan.

b. Sufficient literate, memiliki pengetahuan dan keyakinan tentang lembaga jasa keuangan serta produk dan jasa keuangan, termasuk fitur, manfaat dan risiko, hak dan kewajiban terkait produk dan jasa keuangan.

c. Less literate, hanya memiliki pengetahuan tentang lembaga jasa keuangan, produk dan jasa keuangan.

d. Not literate, tidak memiliki pengetahuan dan keyakinan terhadap lembaga jasa keuangan serta produk dan jasa keuangan, serta tidak memiliki keterampilan dalam menggunakan produk dan jasa keuangan.

Dari hasil survei kepada 20 Pengurus BUMDes di kecamatan Cimaung diperoleh hasil level literasi keuangan seperti yang tercantum di tabel 5 sebagai berikut:

Tabel 5. Hasil Level Literasi Keuangan Pengurus BUMDes Kecamatan Cimaung Kabupaten Bandung Sebelum Pelatihan

\begin{tabular}{lllc}
\hline \multicolumn{1}{c}{ Informasi } & \multicolumn{1}{c}{ LJK } & \multicolumn{1}{c}{ Kriteria } & Persentase \\
\hline Level Literasi & Bank & Well Literate & $38.90 \%$ \\
Finansial & & Sufficient Literate & $54.85 \%$ \\
& & Less Literate & $6.25 \%$ \\
& & Not Literate & 0 \\
& Asuransi & Well Literate & $28.25 \%$ \\
& & Sufficient Literate & $40.85 \%$ \\
& & Less Literate & $23.70 \%$ \\
& & Not Literate & $7.20 \%$ \\
& & & \\
& & Well Literate & $8.30 \%$ \\
& Perusahaan & Sufficient Literate & $12.30 \%$ \\
& Pembiayaan & Less Literate & $11.40 \%$ \\
& IMultifinance & Not Literate & $68.00 \%$ \\
\hline
\end{tabular}

Sumber: hasil survei (diolah)

Dari Tabel 5 di atas dapat dapat dilihat bahwa:

Pertama, Bank, Indeks Literasi Keuangan Pengurus BUMDes adalah 38,90\% yang termasuk kategori memahami, percaya dan terampil dalm penggunaan produk perbankan (well literate). Sedangkan sufficient literate sebesar 54,85\%. Ini artinya pengurus BUMDes pada umumnya diyakini memahami dan memiliki keyakinan terhadap produk perbankan. 


\section{Published December 2019}

EKONOMIKAWAN : Jumal IImu Ekonomi dan Studi Pembangunan

ISSN : $1693-7600$ (Print), ISSN : 2598-0157 (Online), http://jurnal.umsu-ac.id/indexphplekawan

Kedua, Asuransi. Salah satu jasa produk keuangan yang tidak banyak digunakan masyarakat adalah asuransi. Ini terlihat dari $28,25 \%$ termasuk well literate, artinya adalah hanya dua puluh delapan dari seratus orang yang mengerti serta memiliki kepercayaan pada asuransi. Angka tersebut memperlihatkan masih kurang sadarnya pengurus BUMDes tentang perlindungan dirinya. Padahal dengan banyaknya penyakit sekarang ini membuat instrumen asuransi menjadi penting.

Ketiga, Perusahaan Pembiayaan/Multifinace. Hasil survei Indeks Literasi Keuangan untuk Perusahaan Pembiayaan/Multifinance well leterate sebesar 8,3 hingga 0\%. Dan 68\% orang tidak familiar dengan Perusahaan Pembiayaan/Multifinance atau not literate. Dengan indeks rendah Lembaga Perusahaan Pembiayaan/Multifinance berdampak pada pemanfaatan dan penggunaan Perusahaan Pembiayaan/Multifinance yang rendah juga. Dari data hasil tersebut juga diketahui bahwa Perusahaan Pembiayaan/Multifinance yang paling sering ditemui hanyalah perusahaan pembiayaan sepeda motor/mobil.

\section{Pelatihan}

Setelah hasil survei awal di peroleh, maka dilakukan pelatihan keuangan, dengan memilih materi-materi yang diaggap perlu bagi pegurus BUMDes. Peserta pelatihan berjumlah 20 orang, yaitu pengurus yang sudah diikutkan juga dalam tahap survei.

Gambar 2 dan 3 berikut menggambarkan suasana pelatihan.

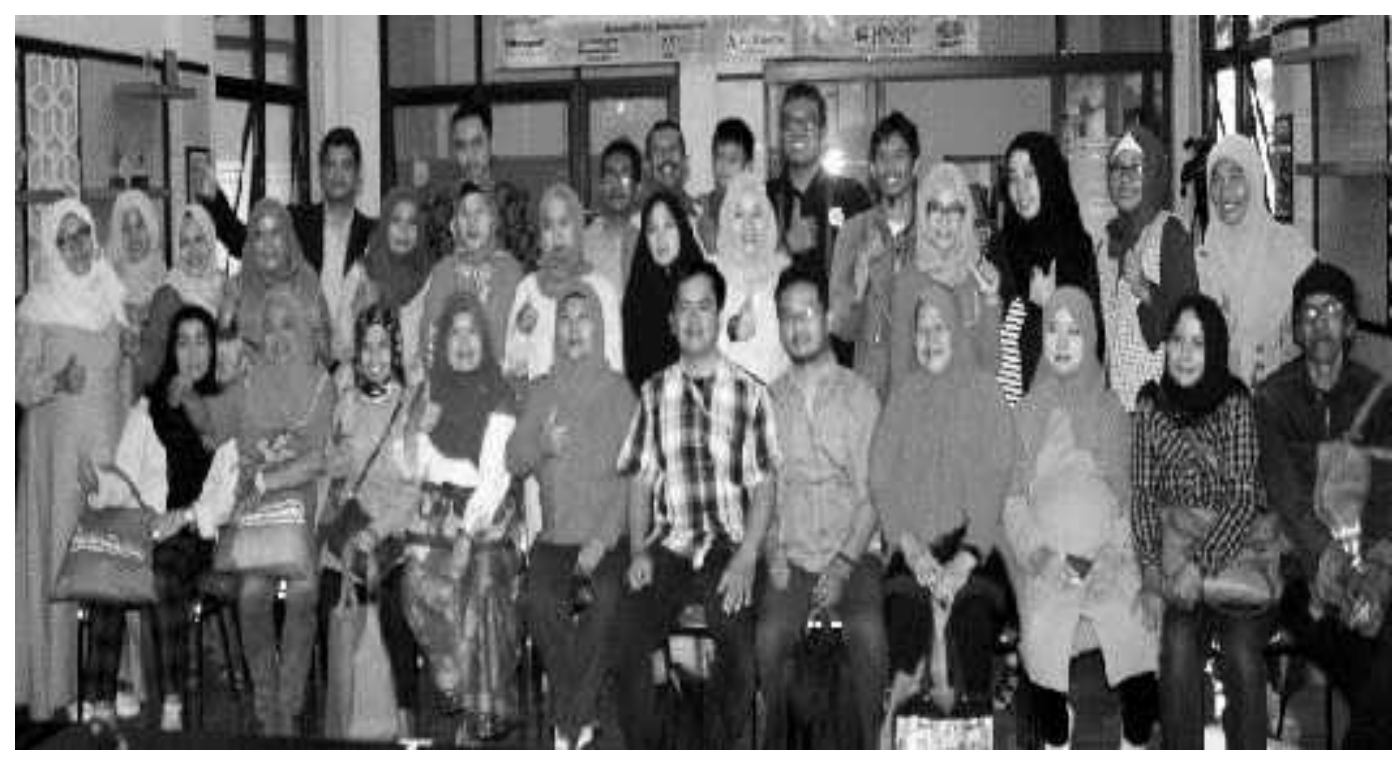

Gambar 2. Peserta Pelatihan

Pelatihan bertempat di Aula Kecamatan Cimaung, Kabupaten Bandung. Dengan menghadirkan tiga orang pemateri. 


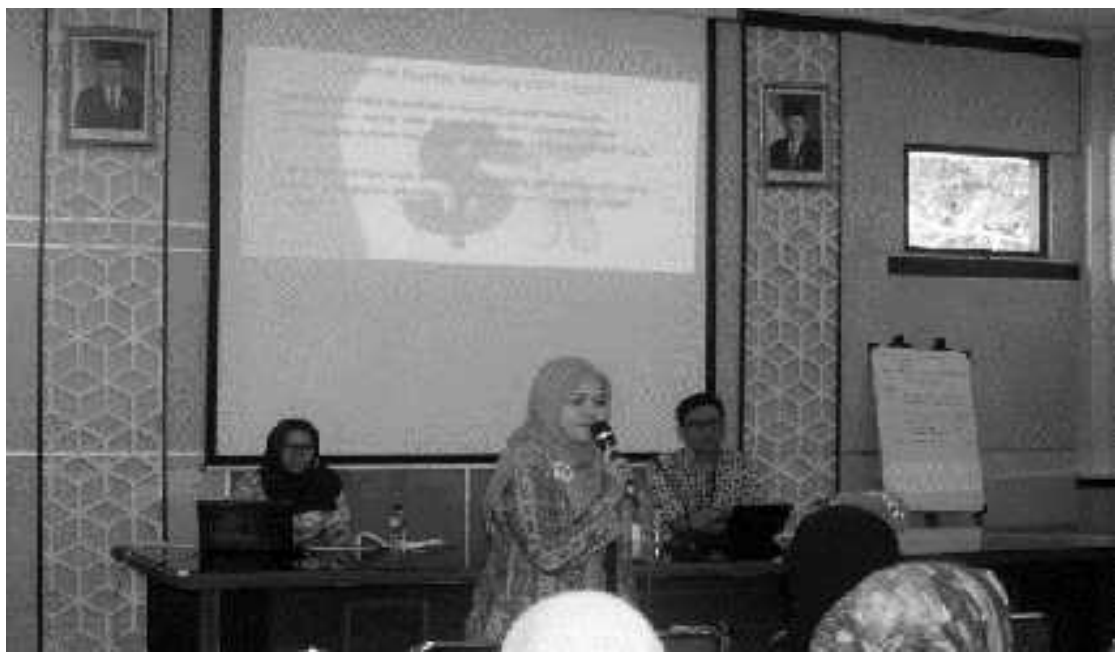

Gambar 3. Penyampaian Materi Pelatihan

Setelah pelatihan selesai, kuesioner kembali dibagikan dan peserta diminta mengisi, untuk melihat perkembangan pengetahuan peserta setelah dilakukan pelatihan. Tabel 5 di bawah ini adalah rekapan hasil dari kuesioner yang telah diisi peserta:

Tabel 5. Hasil Level Literasi Keuangan Pengurus BUMDes Kecamatan Cimaung Kabupaten Bandung Setelah Pelatihan

\begin{tabular}{|c|c|c|c|}
\hline Informasi & LJK & Kriteria & Persentase \\
\hline Level Literasi & \multirow[t]{4}{*}{ Bank } & Well Literate & $41.35 \%$ \\
\hline & & Sufficient Literate & $55.50 \%$ \\
\hline & & Less Literate & $3.15 \%$ \\
\hline & & Not Literate & 0 \\
\hline & \multirow[t]{4}{*}{ Asuransi } & Well Literate & $33.50 \%$ \\
\hline & & Sufficient Literate & $44.75 \%$ \\
\hline & & Less Literate & $15,55 \%$ \\
\hline & & Not Literate & $6.20 \%$ \\
\hline & \multirow{4}{*}{$\begin{array}{l}\text { Perusahaan } \\
\text { Pembiayaan } \\
\text { /Multifinance }\end{array}$} & Well Literate & $13.25 \%$ \\
\hline & & Sufficient Literate & $27.30 \%$ \\
\hline & & Less Literate & $32.10 \%$ \\
\hline & & Not Literate & $27.35 \%$ \\
\hline
\end{tabular}

Sumber: hasil survei (diolah)

Dari Tabel 5 di atas dapat dilihat bahwa:

Pertama, Bank, Indeks Literasi Keuangan Pengurus BUMDes yang well literate naik menjadi $41,35 \%$ artinya pengurus BUMDes yang memahami, percaya dan trampil dalam penggunaan produk perbankan mengalami kenaikan. Sedangkan less literate turun menjadi sebesar $3.15 \%$. Ini artinya pengurus BUMDes yang hanya memiliki pengetahuan tentang lembaga jasa keuangan, produk dan jasa keuangan berkurang. 


\section{Published December 2019}

EKONOMIKAWAN : Jurnal IImu Ekonomi dan Studi Pembangunan

ISSN : $1693-7600$ (Print), ISSN : 2598-0157 (Online), http://jurnal.umsu-ac.id/indexphplekawan

Kedua, Asuransi. Indeks Literasi Keuangan yang termasuk dalam klasifikasi well literate meningkat menjadi sebesar 33,50\%. Yang berarti bahwa terjadi peningkatan pengurus BUMDes yang mengerti dan memiliki kepercayaan pada asuransi. Sedangkan pengurus BUMDes yang Not literate, tidak memiliki pengetahuan dan keyakinan terhadap lembaga jasa keuangan serta produk dan jasa keuangan, serta tidak memiliki keterampilan dalam menggunakan produk dan jasa keuangan atau not literate sebesar 6,20\%.

Ketiga, Perusahaan Pembiayaan/Multifinace. Indeks Literasi Keuangan untuk Perusahaan Pembiayaan/Multifinance well literate terdapat kenaikan dari 8,30\% menjadi $13,25 \%$ artinya terjadi kenaiikan pengus BUMDes yang memiliki pengetahuan dan keyakinan tentang lembaga jasa keuangan serta produk jasa keuangan, termasuk fitur, manfaat dan risiko, hak dan kewajiban terkait produk dan jasa keuangan, serta memiliki keterampilan dalam menggunakan produk dan jasa keuangan. Sedangkan yang not literate menurun drastis dari 68,00\% menjadi sebesar 27,35\%. Artinya pengurus BUMDes yang tidak memiliki pengetahuan dan keyakinan terhadap lembaga jasa keuangan serta produk dan jasa keuangan, serta tidak memiliki keterampilan dalam menggunakan produk dan jasa keuangan. Disamping itu pengurus BUMDes sudah mulai mengenal Perusahaan Pembiayaan/Multifinance seperti anjak piutang, pembiayaan konsumen, dan/atau kartu kredit, tidak hanya sering ditemui seperti Perusahaan Pembiayaan Sepeda Motor/Mobil.

\section{Praktek}

Praktek pembukuan sederhana dan membuat laporan keuangan ini dirasa perlu karena ada kewajiban BUMDes untuk membuat laporan keuangan seluruh unit-unit usaha BUMDes setiap bulan dengan jujur dan transparan.

Pelatihan tetap bertempat di Aula kecamatan Cimaung, kabupaten Bandung, dengan menghadirkan tiga orang pemateri. Praktek ini dilakukan dengan memberikan sebuah kasus. Dengan dipandu pemateri, pengurus BUMDes akan praktek membuat laporan keuangan berupa Neraca, Laporan Laba Rugi, Laporan Perubahan Modal dan laporan Arus Kas. Suasana praktek dapat dilihat pada Gambar 4 di bawah ini:

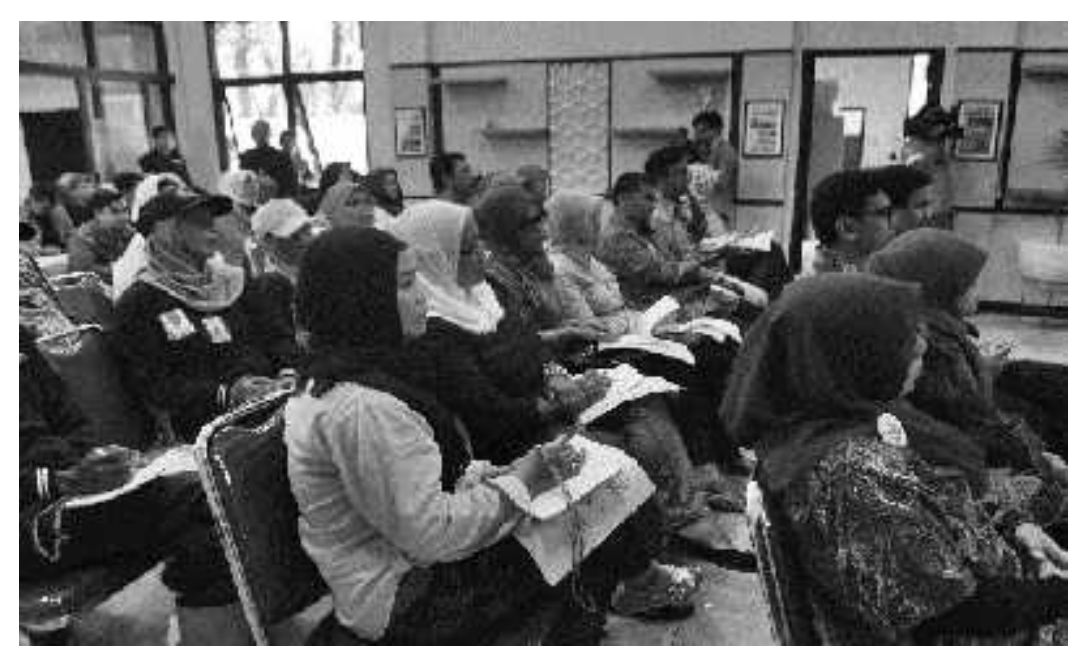

Gambar 4. Suasana Praktek 
Published December 2019

EKONOMIKAWAN : Jurnal IImu Ekonomi dan Studi Pembangunan

ISSN : 1693-7600 (Print), ISSN : 2598-0157 (Online), http://jurnal.umsu.ac.id/indexphp/kkawan

\section{SIMPULAN}

Dari seluruh kegiatan Pegabdian Kepada Masyarakat yang terdiri dari fase survei awal, fase pelatihan dan fase praktek bagi pengurus BUMDes di Kecamatan Cimaung, Kabupaten Bandung, maka dapat disimpulkan beberapa hal sebagai berikut:

1. Pada tahap survei, tingkat literasi keuangan pengurus BUMDes well literate untuk Bank sebesar 38,90\% dan not literate untuk Perusahaan Pembiayaan/Multifinance sebesar $68,00 \%$. Artinya masih perlu dilakukan peningkatan program pendidikan literasi keuangan bagi Pengurus BUMDes untuk memudahkan akses mereka ke bank, asuransi dan perusahaan pembiayaan/Multifinance.

2. Setelah pelatihan ada peningkatan tingkat literasi keuangan pengurus BUMDes well literate untuk Bank menjadi sebesar $41,35 \%$ dan penurunan indeks not literate untuk Perusahaan Pembiayaan/Multifinance menjadi sebesar 27,35\%.

3. Pengurus BUMDes sudah bisa membuat laporan keuangan sederhana. Dengan demikin Pengurus BUMDes bisa memenuhi kewajiban membuat laporan keuangan bulanan dengan cara yang transparan dan jujur bagi bisnis-bisnis di BUMDes tersebut.

\section{DAFTAR PUSTAKA}

Atkinson, A., \& Messy, F. (2013). Assessing Financial Literacy in 12 Countries.

Indonesia, D. P. R. R. (2011). UU nomor 21 tahun 2011 tentang Otoritas Jasa lembaga keuangan.

Keuangan, O. J. (2017). STRATEGI NASIONAL LITERASI KEUANGAN INDONESIA ( Revisit 2017).

Lusardi, A., \& Mitchell, O. S. (2007). Baby Boomer Retirement Security: The Roles of Planning, Financial Literacy, and Housing Wealth Baby Boomer Retirement Security: The Roles of Planning, Financial Literacy, and Housing Wealth. Journal of Monetary Economics, 54, 205-224., 54, 205-224.

Measuring Financial Literacy: Questionnaire and Guidance Notes for Conducting an Internationally Comparable Survey of Financial Literacy. (n.d.).

Menteri Desa, Pembangunan Daerah Tertinggal, dan T. R. I. (2015). Peraturan Menteri Desa, Pembangunan Daerah Tertinggal, dan Transmigrasi Republik Indonesia Nomor 4 Tahun 2015 Tentang Pendirian, Pengurusan dan Pengelolaan dan Pembubaran Badan Usaha Milik Desa, 1-11.

Mishkin, F. S. (2013). The Economics of Money, Banking, and Financial Markets, Global Edition - Tenth Edition, Pearson. (10th Editi). Pearson.

Zulbetti, R. (2012). Pengaruh rasio-rasio camel dan faktor-faktor makroekonomi terhadap. Banking \& Management Review, 1(Mei 2012), 48-62. 